\title{
Intravenous contrast use and acute kidney injury: a retrospective study of 1,238 inpatients undergoing computed tomography
}

Uso de contraste intravenoso e lesão renal aguda: estudo retrospectivo de 1.238 pacientes internados submetidos a tomografia computadorizada

\section{Thyago A. Coser ${ }^{1, a}$, Juliana S. V. Leitão ${ }^{1, b}$, Betina M. Beltrame ${ }^{1, c}$, Luciano S. Selistre ${ }^{1, d}$, Leandro Tasso ${ }^{1, e}$}

1. Universidade de Caxias do Sul (UCS), Caxias do Sul, RS, Brazil.

Correspondence: Dr. Leandro Tasso. Universidade de Caxias do Sul. Avenida Francisco Getúlio Vargas, 1130, Petrópolis. Caxias do Sul, RS, Brazil, 95070-560. Email: Itasso@ucs.br.

a. https://orcid.org/0000-0002-8171-2610; b. https://orcid.org/0000-0002-7426-7758; c. https://orcid.org/0000-0002-8372-6223; d. https://orcid.org/0000-0002-0152-0636; e. https://orcid.org/0000-0001-7102-9204.

Received 30 January 2020. Accepted after revision 6 March 2020.

How to cite this article:

Coser TA, Leitão JSV, Beltrame BM, Selistre LS, Tasso L. Intravenous contrast use and acute kidney injury: a retrospective study of 1,238 inpatients undergoing computed tomography. Radiol Bras. 2021 Mar/Abr;54(2):77-82.

Abstract Objective: To determine the incidence of nephropathy induced by intravenous contrast in hospitalized patients undergoing computed tomography (CT).

Materials and Methods: This was a retrospective cohort study involving 1,238 patients who underwent CT with or without intravenous administration of a contrast agent (iopromide). The primary outcome measure was acute kidney injury (AKI), as defined by the traditional criteria-an absolute or relative increase in serum creatinine ( $\mathrm{SCr}) \geq 0.5 \mathrm{mg} / \mathrm{dL}$ or $\geq 25 \%$ over baseline, respectively, at 2-3 days after contrast administration-and the newer, Kidney Disease: Improving Global Outcomes (KDIGO) criteria-an absolute or relative increase in $\mathrm{SCr} \geq 0.3 \mathrm{mg} / \mathrm{dL}$ or $\geq 50 \%$ over baseline, respectively, at 2-7 days after contrast administration.

Results: The overall incidence of AKI was $11.52 \%$ when the KDIGO criteria were applied. Univariate logistic regression demonstrated a significant association between an absolute post-CT increase in $\mathrm{SCr} \geq 0.5 \mathrm{mg} / \mathrm{dL}$ and AKI, although that association did not retain significance in the multivariate analysis. Multivariate logistic regression initially found an association between an absolute post-CT increase in $\mathrm{SCr} \geq 0.3 \mathrm{mg} / \mathrm{dL}$ and advanced age, although that association was not maintained after correction. We found no association between $\mathrm{AKI}$ and the risk factors evaluated.

Conclusion: We identified no criteria for contrast-induced nephropathy after CT; nor did we find AKI to be associated with the classical risk factors.

Keywords: Acute kidney injury; Tomography, X-ray computed; Contrast media/adverse effects; Contrast media/administration \& dosage; lodine radioisotopes; Creatinine/blood.

Resumo Objetivo: Determinar a incidência de nefropatia induzida por contraste intravenoso em pacientes hospitalizados submetidos a tomografia computadorizada (TC).

Materiais e Métodos: Estudo de coorte retrospectivo que alocou 1.238 pacientes submetidos a TC sem ou com contraste (iopromida). 0 desfecho primário foi nefropatia induzida por contraste, definida pelo critério antigo - aumento absoluto ou relativo na creatinina sérica $(\mathrm{SCr}) \geq 0,5 \mathrm{mg} / \mathrm{dL}$ ou $\geq 25 \%$, respectivamente, durante 2-3 dias após a administração -, e o novo, Kidney Disease Improving Global Outcomes (KDIGO) - aumento absoluto ou relativo na $\mathrm{SCr} \geq 0,3 \mathrm{mg} / \mathrm{dL}$ ou $\geq 50 \%$, respectivamente, durante $2-7$ dias após a administração.

Resultados: A incidência de lesão renal aguda foi de 11,52\% aplicando os critérios KDIGO. A regressão logística univariada demonstrou significância relacionada à associação entre aumento absoluto da $\mathrm{SCr} \geq 0,5 \mathrm{mg} / \mathrm{dL}$ após TC e lesão renal aguda. A regressão logística multivariada encontrou, inicialmente, associação entre aumento absoluto da $\mathrm{SCr} \geq 0,3 \mathrm{mg} / \mathrm{dL}$ após TC e idade avançada, mas a associação não foi mantida após correção. Não foi encontrada associação entre lesão renal aguda e os fatores de risco avaliados.

Conclusão: Não foram encontrados critérios para nefropatia induzida por contraste após TC ou associação de lesão renal aguda com fatores de risco clássicos.

Unitermos: Lesão renal aguda; Tomografia computadorizada; Meios de contraste/efeitos adversos; Meios de contraste/administração \& dosagem; Radioisótopos do iodo; Creatinina/sangue.

\section{INTRODUCTION}

Intravenous administration of iodinated contrast media is widely used during computed tomography $(\mathrm{CT}) \mathrm{ex}^{-}$ aminations because it can increase diagnostic accuracy ${ }^{(1)}$.
However, the use of such media is not risk-free, because they are nephrotoxic and can cause renal dysfunction ${ }^{(2)}$. Medical societies initially defined contrast-induced nephropathy (CIN), manifesting as acute kidney injury (AKI), 
on the basis of the following criteria: an absolute or relative increase in serum creatinine $(\mathrm{SCr}) \geq 0.5 \mathrm{mg} / \mathrm{dL}$ or $\geq 25 \%$ over baseline, respectively, at 2-3 days after contrast administration $^{(3)}$. After the publication of the Kidney Disease: Improving Global Outcomes (KDIGO) study ${ }^{(4)}$, the criteria for CIN were changed to an absolute or relative increase in $\mathrm{SCr} \geq 0.3 \mathrm{mg} / \mathrm{dL}$ or $\geq 50 \%$ over baseline, respectively, at 2-7 days after contrast administration.

In animal models, the pathogenesis of CIN has been shown to consist of classic acute tubular necrosis, secondary to vasoconstriction, accompanied by medullar hypoxia and, thereafter, tubular cell cytotoxicity. Vascular damage occurs due to a reduction in nitric oxide levels, together with increases in endothelin and adenosine in the bloodstream $^{(5)}$.

With an average incidence of $11 \%$, CIN is recognized as the third leading cause of AKI in hospitalized patients ${ }^{(6)}$. However, the reported incidence ranges from $1 \%$ and $50 \%$, depending on the characteristics of the population studied and whether intra-arterial or intravenous contrast is used $^{(7-10)}$. Among patients receiving intravenous contrast alone, the reported incidence of CIN can vary from $2.5 \%$ to $12 \%^{(7-10)}$. The classical risk factors for CIN are female gender, advanced age, diabetes mellitus, cardiovascular disease, infectious processes, chronic kidney disease (CKD), and nephrotoxic drug use $\mathrm{e}^{(4-11)}$.

Most studies in the literature address CIN after the administration of intra-arterial contrast, few having evaluated it after intravenous contrast administration. In view of the small number of studies of the latter topic ${ }^{(1,11-18)}$, we carried out the present study to evaluate the relationship between intravenous contrast administration and CIN in hospitalized patients, as well as to determine the influence that classical risk factors have on that relationship.

\section{MATERIALS AND METHODS}

This was a single-center retrospective cohort study, conducted between August 1, 2010 and April 30, 2017 at the General Hospital of Caxias do Sul, located in the city of Caxias do Sul, Brazil, which is a regional referral center serving a population of 1.5 million people. The study was approved by the Research Ethics Committee of the University of Caxias do Sul (Reference no. 1880766). All of the authors signed a confidentiality agreement to ensure the anonymity of the data obtained from the electronic medical records of the hospital.

Between August 1, 2010 and April 30, 2017, a total of 129,205 patients were admitted to the General Hospital of Caxias do Sul, and 5,159 inpatients underwent CT. We analyzed the electronic medical records of those 5,159 patients, comparing the incidence of CIN between those who received intravenous contrast and those who did not receive any contrast.

The SCr level was tracked by isotope dilution mass spectrometry. Contrast administration was performed in accordance with the institutional protocol, which calls for intravenous infusion of the non-ionic contrast agent iopromide (Ultravist 300; Bayer AG, Berlin, Germany) at a concentration of $623 \mathrm{mg} / \mathrm{mL}$ (equivalent to $300 \mathrm{mg} / \mathrm{mL}$ of iodine), with an osmolality of $0.59 \mathrm{mOsm} / \mathrm{kg}$.

The following inclusion criteria were applied: having been admitted to the hospital; having undergone CT, with or without contrast enhancement; having been $\geq 18$ years of age on the date of the CT; having undergone SCr determination at baseline and at $48 \mathrm{~h}$ after CT; having had stable renal function during the 3 months preceding the CT examination; and having had a baseline SCr of 0.4-4.0 $\mathrm{mg} / \mathrm{dL}$. Patients who had not shown an absolute increase in $\mathrm{SCr} \geq 0.3 \mathrm{mg} / \mathrm{dL}$ over a 48 -h period, a relative increase in $\mathrm{SCr} \geq 1.5$ times the baseline value over a 7 -day period, or diuresis $<0.5 \mathrm{~mL} / \mathrm{kg} / \mathrm{h}$ over a 6 -h period were categorized as having stable renal function ${ }^{(2)}$. Patients on dialysis were excluded, as were those in whom contrast media had been administered for other radiological purposes in the $48 \mathrm{~h}$ prior to the CT examination. On the basis of the study criteria, 3,921 patients were excluded. Therefore, the final sample comprised 1,238 patients, of whom $642(51.85 \%)$ underwent contrast-enhanced CT and 596 (48.15\%) underwent unenhanced CT.

To look for correlations with CIN, we analyzed the following explanatory variables: age; gender; advanced age ( $\geq 65$ years); diabetes mellitus, as defined in the International Diabetes Federation guidelines ${ }^{(19)}$; cardiovascular disease, as defined in the New York Heart Association Functional Classification ${ }^{(20)}$; sepsis, as defined by the Latin American Sepsis Institute ${ }^{(21)}$; CKD, diagnosed in accordance with the $2012 \mathrm{KDIGO}$ criteria $^{(4)}$; obesity, defined as a body mass index $\geq 30 \mathrm{~kg} / \mathrm{m}^{2}$, as established by the World Health Organization ${ }^{(22)}$; the previous use of nephrotoxic drugs, including angiotensin-converting enzyme inhibitors, angiotensin receptor blockers, nonsteroidal anti-inflammatory drugs, aminoglycosides, and others; and the use of preventive measures (crystalloids, sodium bicarbonate, or $\mathrm{N}$-acetylcysteine). The primary outcome measure was CIN. The criteria for AKI were increases in $\mathrm{SCr}$ at $48 \mathrm{~h}$ after CT, based on the KDIGO criteria (0.3 $\mathrm{mg} / \mathrm{dL}$ or $50 \%$ over baseline) or on the traditional criteria $(0.5 \mathrm{mg} / \mathrm{dL}$ or $25 \%$ over baseline $)$. In addition to evaluating the risk factors for CIN listed above, we attempted to determine whether the contrast volume affected the postCT level of SCr and whether the adoption of preventive measures reduced the incidence of CIN, the secondary outcome measures therefore being the post-CT level of $\mathrm{SCr}$ and the incidence of CIN.

\section{Statistical modeling}

Continuous variables are expressed as mean and standard deviation, whereas categorical variables are presented as absolute and relative values. Differences in proportions were assessed by the chi-square test, when indicated. The 
normality of the distribution of continuous variables was calculated with the Shapiro-Wilk test. Student's t tests were used for comparisons between continuous variables. The variables that differed between patients with and without CIN were analyzed by stepwise logistic regression with backward selection, and the Wald test was used in order to look for associations with the occurrence of CIN. To quantify the effects, we calculated odds ratios (ORs) and the respective 95\% confidence intervals (95\% CIs).

The statistical analysis was performed with the software $\mathrm{R}$ for Windows, version 3.3.2 (R Development Core Team-www.r-project.org). We aimed to avoid information bias by robust selection and statistical analysis.

\section{RESULTS}

On the basis of the study criteria, we excluded a total of 3,921 patients. Therefore, the final sample comprised 1,238 patients, corresponding to $24.0 \%$ of the eligible patients. Of those 1,238 patients, $642(51.85 \%)$ underwent contrast-enhanced CT and 596 (48.15\%) underwent unenhanced CT.

The demographic, clinical, and biochemical characteristics of the sample are presented in Table 1. Of the 1,238 patients, $723(58.41 \%)$ were men and $515(41.59 \%)$ were women. The mean age was $60.8 \pm 16.1$ years in the sample as a whole, being significantly higher in the patients who underwent unenhanced CT than in those who underwent contrast-enhanced CT $(63.5 \pm 16.08$ vs. 59.3 \pm 15.8 years; $p<0.01)$. Comparing the patients who underwent unenhanced CT with those who underwent contrast-enhanced CT, we found that $40.03 \%$ and $54.53 \%$, respectively, were $\geq 65$ years of age $(p<0.01) ; 16.66 \%$ and $23.82 \%$, respectively, had diabetes mellitus $(p=0.013)$; $25.54 \%$ and $46.30 \%$, respectively, had CKD $(p<0.01)$; and $19.62 \%$ and $11.74 \%$, respectively, had been submitted to preventive measures $(p<0.01)$. The other variables related to the characteristics of the patients did not differ between those who underwent unenhanced CT and those who underwent contrast-enhanced CT. As can also be seen in Table 1, the median SCr level was lower in the patients who underwent contrast-enhanced CT than in those who underwent unenhanced CT, at baseline $(0.8$ $\mathrm{mg} / \mathrm{dL}$ vs. $1.1 \mathrm{mg} / \mathrm{dL} ; p<0.01)$ and at $48 \mathrm{~h}$ after CT $(0.8$ $\mathrm{mg} / \mathrm{dL}$ vs. $1.05 \mathrm{mg} / \mathrm{dL} ; p<0.01$ ).

The univariate logistic regression showed that an absolute post-CT increase in $\mathrm{SCr} \geq 0.5 \mathrm{mg} / \mathrm{dL}$ correlated significantly with the incidence of AKI $(\mathrm{OR}=5.4 ; 95 \% \mathrm{CI}$ : $1.45-20.15 ; p=0.02)$. However, the incidence of AKI was not found to correlate significantly with an absolute postCT increase in $\mathrm{SCr} \geq 0.3 \mathrm{mg} / \mathrm{dL}$ or with a relative post-CT increase in SCr $\geq 25 \%$ or $\geq 50 \%$ over baseline (Table 2 ). Applying the KDIGO criteria, we found that the incidence of AKI among the patients who underwent contrast-enhanced CT was $11.52 \%$ when based on the absolute postCT increase in SCr and 7.47\% when based on the relative post-CT increase in SCr (Table 3).

Table 4 shows the results of the multivariate logistic regression of the explanatory variables in relation to the absolute post-CT increases in $\mathrm{SCr} \geq 0.3 \mathrm{mg} / \mathrm{dL}$ and $0.5 \mathrm{mg} /$ $\mathrm{dL}$, as well as in relation to the relative post-CT increases in

Table 2-Increase in serum creatinine after CT.

\begin{tabular}{lccc}
\hline Post-CT increase in SCr & OR & $95 \% \mathrm{Cl}$ & $P$ \\
\hline$\geq 0.3 \mathrm{mg} / \mathrm{dL}$ & 1.15 & $0.62-2.15$ & 0.65 \\
$\geq 0.5 \mathrm{mg} / \mathrm{dL}$ & 5.4 & $1.45-20.15$ & 0.02 \\
$\geq 25 \%$ over baseline & 2.6 & $0.90-7.4$ & 0.07 \\
$\geq 50 \%$ over baseline & 3.5 & $0.92-13.1$ & 0.06 \\
\hline
\end{tabular}

Table 3-Incidence of AKI after CT, with and without intravenous contrast administration, by post-CT increase in SCr.

\begin{tabular}{lccc}
\hline & \multicolumn{4}{c}{ AKI after CT } \\
\cline { 2 - 4 } & \multicolumn{3}{c}{ All } \\
Post-CT increase in SCr & $(\mathrm{n}=1,238)$ & $\begin{array}{c}\text { Contrast-enhanced } \\
(\mathrm{n}=642)\end{array}$ & $\begin{array}{c}\text { Unenhanced } \\
(\mathrm{n}=596)\end{array}$ \\
\hline$\geq 0.3 \mathrm{mg} / \mathrm{dL}, \mathrm{n}(\%)$ & $197(15.91)$ & $74(11.52)$ & $123(20.63)$ \\
$\geq 0.5 \mathrm{mg} / \mathrm{dL}, \mathrm{n}(\%)$ & $128(10.33)$ & $41(6.38)$ & $87(14.59)$ \\
$\geq 25 \%$ over baseline, $\mathrm{n}(\%)$ & $229(18.49)$ & $102(15.88)$ & $127(21.30)$ \\
$\geq 50 \%$ over baseline, $\mathrm{n}(\%)$ & $113(9.12)$ & $48(7.47)$ & $65(10.90)$ \\
\hline
\end{tabular}

Table 1-Demographic, clinical, and biochemical characteristics of patients undergoing CT with and without intravenous contrast administration.

\begin{tabular}{|c|c|c|c|c|}
\hline Characteristic & All $(n=1,238)$ & Contrast-enhanced $(n=642)$ & Unenhanced $(\mathrm{n}=596)$ & $P$ \\
\hline Age (years), mean \pm SD & $60.8 \pm 16.1$ & $59.3 \pm 15.8$ & $63.5 \pm 16.08$ & $<0.01$ \\
\hline Female gender, n (\%) & 515 (41.59) & $248(38.62)$ & 267 (44.79) & 1.00 \\
\hline Advanced age, n (\%) & $582(47.01)$ & $257(40.03)$ & $325(54.53)$ & $<0.01$ \\
\hline Diabetes mellitus, n (\%) & $249(20.11)$ & $107(16.66)$ & $142(23.82)$ & 0.013 \\
\hline Cardiovascular disease, n (\%) & $109(8.80)$ & $36(5.60)$ & $73(12.24)$ & 0.129 \\
\hline Infection, n (\%) & $201(16.23)$ & $107(16.66)$ & $94(15.77)$ & 0.726 \\
\hline CKD, n (\%) & $440(35.54)$ & $164(25.54)$ & $276(46.30)$ & $<0.01$ \\
\hline Obesity, n (\%) & $95(7.67)$ & 52 (8.09) & $43(7.21)$ & 1.00 \\
\hline Previous nephrotoxic drug use, n (\%) & $712(57.51)$ & $366(57.01)$ & $348(58.38)$ & 0.448 \\
\hline CIN preventive measures, n (\%) & $196(15.83)$ & $126(19.62)$ & $70(11.74)$ & $<0.01$ \\
\hline Baseline SCr (mg/dL), median (IQR) & $1.27(0.6-1.4)$ & $0.8(0.62-1.2)$ & $1.1(0.8-1.6)$ & $<0.01$ \\
\hline $48 \mathrm{~h}$ post-CT $\mathrm{SCr}(\mathrm{mg} / \mathrm{dL})$, median (IQR) & $1.30(0.6-1.4)$ & $0.8(0.6-1.1)$ & $1.05(0.7-1.6)$ & $<0.01$ \\
\hline
\end{tabular}

IQR, interquartile range 
Table 4-Risk factors for AKI after CT, by post-CT increase in SCr.

\begin{tabular}{|c|c|c|c|}
\hline Variable & OR & $95 \% \mathrm{Cl}$ & $P$ \\
\hline \multicolumn{4}{|l|}{ Post-CT increase in $\mathrm{SCr} \geq 0.3 \mathrm{mg} / \mathrm{dL}$} \\
\hline \multicolumn{4}{|l|}{ Risk factors } \\
\hline Contrast use & 0.72 & $0.42-1.24$ & 0.24 \\
\hline Female gender & 1.22 & $0.70-2.11$ & 0.48 \\
\hline Advanced age & 1.77 & $1.01-3.11$ & 0.05 \\
\hline Diabetes mellitus & 0.63 & $0.31-1.28$ & 0.20 \\
\hline Cardiovascular disease & 0.78 & $0.25-2.41$ & 0.67 \\
\hline Infection & 1.40 & $0.72-2.72$ & 0.32 \\
\hline CKD & 1.25 & $0.69-2.24$ & 0.46 \\
\hline Obesity & 1.26 & $0.64-2.47$ & 0.51 \\
\hline Previous nephrotoxic drug use & 0.88 & $0.51-1.51$ & 0.64 \\
\hline \multicolumn{4}{|l|}{ Post-CT increase in $\mathrm{SCr} \geq 0.5 \mathrm{mg} / \mathrm{dL}$} \\
\hline \multicolumn{4}{|l|}{ Risk factors } \\
\hline Contrast use & 0.82 & $0.41-1.64$ & 0.58 \\
\hline Female gender & 1.20 & $0.59-2.45$ & 0.61 \\
\hline Advanced age & 1.37 & $0.66-2.83$ & 0.40 \\
\hline Diabetes mellitus & 0.48 & $0.18-1.26$ & 0.14 \\
\hline Cardiovascular disease & 0.61 & $0.13-2.81$ & 0.53 \\
\hline Infection & 1.61 & $0.72-3.61$ & 0.25 \\
\hline CKD & 1.57 & $0.74-3.34$ & 0.24 \\
\hline Obesity & 2.18 & $0.98-4.83$ & 0.06 \\
\hline Previous nephrotoxic drug use & 1.14 & $0.57-2.30$ & 0.71 \\
\hline \multicolumn{4}{|l|}{$\begin{array}{l}\text { Post-CT increase in } \mathrm{SCr} \geq 25 \% \text { over } \\
\text { baseline }\end{array}$} \\
\hline \multicolumn{4}{|l|}{ Risk factors } \\
\hline Contrast use & 1.08 & $0.65-1.79$ & 0.76 \\
\hline Female gender & 1.28 & $0.76-2.14$ & 0.35 \\
\hline Advanced age & 1.38 & $0.82-2.34$ & 0.23 \\
\hline Diabetes mellitus & 0.76 & $0.39-1.48$ & 0.42 \\
\hline Cardiovascular disease & 1.04 & $0.37-2.91$ & 0.94 \\
\hline Infection & 1.65 & $0.90-3.03$ & 0.10 \\
\hline CKD & 0.69 & $0.38-1.24$ & 0.22 \\
\hline Obesity & 1.08 & $0.57-2.04$ & 0.82 \\
\hline Previous nephrotoxic drug use & 0.87 & $0.53-1.43$ & 0.59 \\
\hline \multicolumn{4}{|l|}{$\begin{array}{l}\text { Post-CT increase in } \mathrm{SCr} \geq 50 \% \text { over } \\
\text { baseline }\end{array}$} \\
\hline \multicolumn{4}{|l|}{ Risk factors } \\
\hline Contrast use & 0.87 & $0.43-1.78$ & 0.71 \\
\hline Female gender & 0.87 & $0.43-1.77$ & 0.70 \\
\hline Advanced age & 1.53 & $0.74-3.19$ & 0.25 \\
\hline Diabetes mellitus & 0.59 & $0.22-1.55$ & 0.28 \\
\hline Cardiovascular disease & 0.34 & $0.04-2.63$ & 0.30 \\
\hline Infection & 1.50 & $0.64-3.48$ & 0.35 \\
\hline CKD & 0.72 & $0.32-1.66$ & 0.45 \\
\hline Obesity & 2.12 & $0.96-4.68$ & 0.06 \\
\hline Previous nephrotoxic drug use & 1.13 & $0.55-2.29$ & 0.74 \\
\hline
\end{tabular}

SCr $\geq 25 \%$ and $\geq 50 \%$ over baseline. Another point worth noting is that the multivariate analysis revealed that AKI showed a significant positive association only with an absolute post-CT increase in $\mathrm{SCr} \geq 0.3 \mathrm{mg} / \mathrm{dL}$ and only in the elderly patients (OR: 1.77 ; 95\% CI: $1.01-3.11 ; p=0.05$ ), although that association did not retain its significance after correction.

\section{DISCUSSION}

Initial reports on CIN inferred a strong association between intra-arterial contrast use (for angiographic procedures) and AKI. Because of that relevant incidence, other studies were conducted in order to determine whether CT examinations performed with intravenous contrast were associated with $\mathrm{AKI}^{(1,11-18)}$.

In the present study, we expected that some patients would develop CIN within the first $48 \mathrm{~h}$ after contrast injection, especially because we used a contrast agent with an osmolality of $0.59 \mathrm{mOsm} / \mathrm{kg}$ (formerly referred to as "low osmolar contrast") rather than an iso-osmolar contrast agent. However, we did not observe a relevant increase in $\mathrm{SCr}$ in the patients undergoing procedures involving the use of intravenous contrast. Because this was a retrospective study, one possible explanation for this result is that the medical indications for intravenous contrast administration were not homogeneous, having been set by the institutional protocol, although the clinical characteristics, risk factors, and preventive measures were probably taken into account. This result is corroborated by evidence in recent studies showing that the incidence of CIN after intravenous contrast administration is relatively low ${ }^{(1,14-17)}$. However, many of those were also retrospective studies. The authors of those studies concluded that intravenous contrast administration is not a risk factor for AKI, even in patients with impaired renal function or with comorbidities that can predispose to nephrotoxicity ${ }^{(1,15-17)}$. Nevertheless, other authors have concluded that intravenous contrast administration is a risk factor for AKI in patients with CKD and diabetes mellitus ${ }^{(7,9,10,18)}$.

In the present study, the incidence of AKI was $11.52 \%$ when we applied the KDIGO criteria, although it was not found to be associated with intravenous contrast use. In two meta-analyses, evaluating 42 and 40 articles, respectively, the respective incidence of CIN after intravenous contrast administration was $4.96 \%$ and $6.4 \%{ }^{(9,10)}$. In another retrospective study, involving 126 patients with a glomerular filtration rate $(\mathrm{GFR})<60 \mathrm{~mL} / \mathrm{min} / 1.73 \mathrm{~m}^{2}$, the incidence of CIN was found to be $5.1 \%{ }^{(8)}$. In a heterogeneous prospective cohort of patients undergoing contrastenhanced CT, $11 \%$ developed AKI consistent with $\mathrm{CIN}^{(2)}$.

In the univariate logistic regression, we found a statistically significant association between an absolute post$\mathrm{CT}$ increase in $\mathrm{SCr} \geq 0.5 \mathrm{mg} / \mathrm{dL}$ and AKI. However, that association did not retain its significance after adjustment for the use of contrast and risk factors in the multivariate logistic regression. Similarly, the positive association between an absolute post-CT increase in $\mathrm{SCr} \geq 0.3 \mathrm{mg} /$ $\mathrm{dL}$ and advanced age did not retain its significance after correction in the multivariate analysis. We found no other associations with classical risk factors, thus corroborating the results of previous studies ${ }^{(1,11,14-17)}$.

Our study has some limitations. Because it was a retrospective study in which data were collected from electronic 
medical records, some relevant information was missing. Consequently, we were unable to analyze the association between contrast volume and post-CT SCr, because patient height was not noted in $943(76.17 \%)$ of the medical records reviewed. That underscores the need to measure and register such data in medical records. Despite the missing data and the fact that the contrast dose was not adjusted to the specific needs of the individual patients, we found no association between contrast use and AKI, thus supporting the hypothesis that the use of contrast during CT does not induce CIN. Another potential limitation is the fact that the proportion of patients who were elderly was significantly higher among the patients who underwent unenhanced CT, as was that of those who had diabetes mellitus and that of those who had CKD. That was probably because physicians had contraindicated the use of contrast on the basis of the medical history of those patients. In contrast, preventive measures were used at a significantly higher rate in the patients who underwent contrast-enhanced CT. That could explain the lack of differences between the two groups in terms of the incidence of CIN. Many studies have used propensity matching analysis to avoid these differences among groups in retrospective studies ${ }^{(23)}$.

The Royal College of Radiology recommends the infusion of $0.9 \%$ saline solution for patients at risk for $\mathrm{CIN}^{(24)}$. A recent randomized clinical trial showed that intravenous hydration did not reduce the incidence of CIN for patients with a GFR of $30-59 \mathrm{~mL} / \mathrm{min} / 1.73 \mathrm{~m}^{2}$, suggesting that intravenous rehydration should be reserved for patients with a GFR $<30 \mathrm{~mL} / \mathrm{min} / 1.73 \mathrm{~m}^{2(25)}$. Another study suggested that CIN preventive measures were not effective in a population of patients undergoing CT and stratified into subgroups according to baseline GFR: $\geq 90,60-89,30-59$, and $<30 \mathrm{~mL} / \mathrm{min} / 1.73 \mathrm{~m}^{2(13)}$. In our investigation, CIN was not found. Therefore, the value of preventive measures as a protective factor for AKI after intravenous contrast use could not be evaluated.

In our sample, there was an increase in SCr at $48 \mathrm{~h}$ after CT in both groups of patients (those who received intravenous contrast and those who did not). Therefore, SCr was not associated with the use of contrast; nor was it associated with any of the classical risk factors studied. Many studies have shown that there is day-to-day variability in creatinine levels in hospitalized patients, which can be related to the underlying disease, to the indication for the $\mathrm{CT}$, or even to iatrogenic causes. Although further studies are needed in order to identify possible associated factors, the risk of CIN has been overestimated in clinical practice ${ }^{(26)}$. The results of the present study are valid for our hospital but cannot be generalized to other institutions.

\section{CONCLUSION}

In our study, the incidence of AKI was $11.52 \%$. We identified no other criteria for CIN after CT. We also found no association between AKI and classical risk factors. This corroborates the current literature, in which the incidence of CIN after intravenous contrast administration seems to be lower than previously thought.

\section{Acknowledgments}

The authors are grateful to the faculty of the University of Caxias do Sul Graduate Program in Health Sciences and to the staff of the teaching department of the General Hospital of Caxias do Sul.

\section{REFERENCES}

1. Hinson JS, Ehmann MR, Fine DM, et al. Risk of acute kidney injury after intravenous contrast media administration. Ann Emerg Med. 2017;69:577-86.e4.

2. Mitchell AM, Kline JA, Jones AE, et al. Major adverse events one year after acute kidney injury after contrast-enhanced computed tomography. Ann Emerg Med. 2015;66:267-74.e4.

3. Maioli M, Toso A, Leoncini M, et al. Persistent renal damage after contrast-induced acute kidney injury: incidence, evolution, risk factors, and prognosis. Circulation. 2012;125:3099-107.

4. Kellum JA, Lameire N, Aspelin P, et al. Kidney disease: improving global outcomes (KDIGO) acute kidney injury work group. KDIGO clinical practice guideline for acute kidney injury. Kidney International Supplements. 2012;2(1):1-138.

5. Detrenis S, Meschi M, Musini S, et al. Lights and shadows on the pathogenesis of contrast-induced nephropathy: state of the art. Nephrol Dial Transplant. 2005;20:1542-50.

6. Nash K, Hafeez A, Hou S. Hospital-acquired renal insufficiency. Am J Kidney Dis. 2002;39:930-6.

7. Peer S, Choh NA, Gojwari TA. Incidence of contrast-induced nephropathy a prospective study. Jornal of Renal Injury Prevention. 2017;6:192-8.

8. Fukushima Y, Miyazawa H, Nakamura J, et al. Contrast-induced nephropathy (CIN) of patients with renal dysfunction in CT examination. Jpn J Radiol. 2017;35:427-31.

9. Kooiman J, Pasha SM, Zondag W, et al. Meta-analysis: serum creatinine changes following contrast enhanced CT imaging. Eur J Radiol. 2012;81:2554-61.

10. Moos SI, van Vemde DNH, Stoker J, et al. Contrast induced nephropathy in patients undergoing intravenous (IV) contrast enhanced computed tomography (CECT) and the relationship with risk factors: a meta-analysis. Eur J Radiol. 2013;82:387-99.

11. Rao QA, Newhouse JH. Risk of nephropathy after intravenous administration of contrast material: a critical literature analysis. Radiology. 2006;239:392-7.

12. Newhouse JH, Kho D, Rao QA, et al. Frequency of serum creatinine changes in the absence of iodinated contrast material: implications for studies of contrast nephrotoxicity. AJR Am J Roentgenol. 2008;191:376-82.

13. McDonald JS, McDonald RJ, Carter RE, et al. Risk of intravenous contrast material-mediated acute kidney injury: a propensity scorematched study stratified by baseline-estimated glomerular filtration rate. Radiology. 2014;271:65-73.

14. McDonald JS, McDonald RJ, Comin J, et al. Frequency of acute kidney injury following intravenous contrast medium administration: a systematic review and meta-analysis. Radiology. 2013;267:1 19-28.

15. McDonald RJ, McDonald JS, Carter RE, et al. Intravenous contrast material exposure is not an independent risk factor for dialysis or mortality. Radiology. 2014;273:714-25.

16. McDonald RJ, McDonald JS, Bida JP, et al. Intravenous contrast material-induced nephropathy: causal or coincident phenomenon? Radiology. 2013;267:106-18.

17. Zealley I, Wang H, Donnan PT, et al. Exposure to contrast media in 
the perioperative period confers no additional risk of acute kidney injury in surgical patients. Nephrol Dial Transplant. 2018;33:1751-6.

18. Davenport MS, Khalatbari S, Cohan RH, et al. Contrast materialinduced nephrotoxicity and intravenous low-osmolality iodinated contrast material: risk stratification by using estimated glomerular filtration rate. Radiology. 2013;268:719-28.

19. American Diabetes Association. Standards of medical care in diabetes. Diabetes Care. 2019;42(Suppl 1):S1-193.

20. Dolgin M; New York Heart Association, Criteria Committee. Nomenclature and criteria for diagnosis of diseases of the heart and great vessels. 9th ed. Boston, MA: Little, Brown \& Co.; 1994.

21. Conselho Federal de Medicina/Instituto Latino-Americano de Sepse. [Sepsis: a public health problem]. Brasília, DF: Conselho Federal de Medicina; 2015. [cited 2020 Aug 25]. Available from: https://www. ilas.org.br/assets/arquivos/ferramentas/livro-sepse-um-problema-desaude-publica-cfm-ilas.pdf.

22. WHO Expert Committee on Physical Status: the use and interpre- tation of anthropometry. Geneva, Switzerland: World Health Organization; 1995.

23. Chaudhury P, Armanyous S, Harb SC, et al. Intra-arterial versus intravenous contrast and renal injury in chronic kidney disease: a propensity-matched analysis. Nephron. 2019;141:31-40.

24. Cope LH, Drinkwater KJ, Howlett DC. Re: RCR audit of compliance with UK guidelines for the prevention and detection of acute kidney injury in adult patients undergoing iodinated contrast media injections for CT. A reply. Clin Radiol. 2018;73:389-90.

25. Nijssen EC, Rennenberg RJ, Nelemans PJ, et al. Prophylactic hydration to protect renal function from intravascular iodinated contrast material in patients at high risk of contrast-induced nephropathy (AMACING): a prospective, randomised, phase 3, controlled, open-label, non-inferiority trial. Lancet. 2017;389:1312-22.

26. Luk L, Steinman J, Newhouse JH. Intravenous contrast-induced nephropathy - the rise and fall of a threatening idea. Adv Chronic Kidney Dis. 2017;24:169-75. 